\title{
The Variation of Betulinic Acid Content of Andalas Tree (Morus macroura var. Macroura) in Different Localities of West Sumatra
}

\author{
Nindi Aseny ${ }^{1}$ Erma Nur Atika ${ }^{1}$ Syamsuardi ${ }^{1, *}$ Friardi Ismed ${ }^{2,3}$ \\ ${ }^{1}$ Department of Biology, Faculty of Mathematics and Natural Sciences, Andalas University, Padang 25163, \\ Indonesia \\ ${ }^{2}$ Faculty of Pharmacy, Andalas University, Padang 25163, Indonesia \\ ${ }^{3}$ Sumatran Biota Laboratory, Andalas University, Padang 25163, Indonesia \\ *Corresponding author. Email: syamsuardi@sci.unand.ac.id
}

\begin{abstract}
Recently, herbal ingredients have been utilized as candidate supplements or drugs to increase the resistance of body against diseases caused by viruses. In general, research is focused on plants used as herbal medicine in Indonesia. Sumatran mulberry (Morus macroura var. Macroura) is the native plant tree species in West Sumatra with the local name of the Andalas tree that has the potential to be used as a medicinal plant against the viruses desease due to its betulinic acid content. The content of secondary metabolites in a plant species can vary due to the influence of various environmental factors in their habitats. This study explored the content of betulinic acid of Morus macroura var. Macroura from four different locations in West Sumatra (Tanjung Bungo, Nagari Koto Hilalang, Paninjauan and Andaleh). Sample extracted from leaves and the level of content were examined using the Densitometric Thin-layer Chromatography (TLC) methods with the pure betulinic acid commpound as a standar. In this paper, we describe the various content of betulinic acid of Andalas Tree and discuss its potentiality as source of medicinal product based on the recent references.
\end{abstract}

Keywords: Andalas tree, betulinic acid, chemical contents, different habitats, Morus macroura var. Macroura.

\section{INTRODUCTION}

Sumatra is the largest island in Indonesia territory with the highest biodiversity, especially ecosystems, species, genetics. The diverse forest gives the community some benefit for several purposes, such as traditional medicine.[1] The Andalas tree in origin of Sumatra is Morus macraura var macraura [2] and this plant has a potential compound for tradisional medicine. But, this tree population is currently threatened [3].

The Andalas tree also contained antimicrobial, anti-tumor compounds and antioxidants. These compounds can potentially be raw materials for the pharmaceutical industry, such as hydroxytridecanildodecanoate, triterpenoids, tetracyclic acetates, and $\beta$-sitosterol betulinic acid, triisoprenyl flavanol and moracin B [4]. This plant contained betulinic acid compound which could inhibit human immunodeficiency virus type 1 (HIV-1) [5].

The bioprospection results of native tropical plants can be used as a treatment for yet incurable diseases, such as andalas which can inhibit HIV-1 [5]. The chemical potential of the Andalas tree is quite enormous and needs to be explored. One of the Andalas tree prospects is betulinic acid. This compound can be a natural medicine source that can be used sustainably. In this study, We analyzed natural chemical compounds (betulinic acid) from four regions in West Sumatra.

\section{MATERIAL AND METHODS}

\subsection{Locations}

Plant sampling was conducted in four locations in West Sumatra; Jorong Koto Hilalang, Agam Regency 
Nagari Tanjung Bungo, Lima Puluh Kota Regency, Nagari Andaleh and Nagari Panininjau Tanah Datar Regency (Figure 1) and the analysis has been carried out at Pharmacy Laboratory and Sumatran Biota Laboratory, Andalas University.

\subsection{Tools and Materials}

The tools used in the metabolite compound test were erlenmeyer, rotary evaporator, grinder, capillary tube,
TLC silica gel 60 F254 plate, one distillation unit, TLC Chamber, and TLC Scanner. The materials used in the metabolite compound test were dry $M$. macroura leaf samples, dichloromethane, methanol, acetic acid, formic acid, ethanol, LiebermanBurchard (50 ml ethanol PA: $5 \mathrm{ml}$ acetic acid: $5 \mathrm{ml}$ acetic anhydride), anisaldehyde reagent $10 \mathrm{~mL}(9.8$ $\mathrm{ml}$ mixture of anisaldehyde and 10 drops of $\mathrm{H} 2 \mathrm{SO} 4)$.

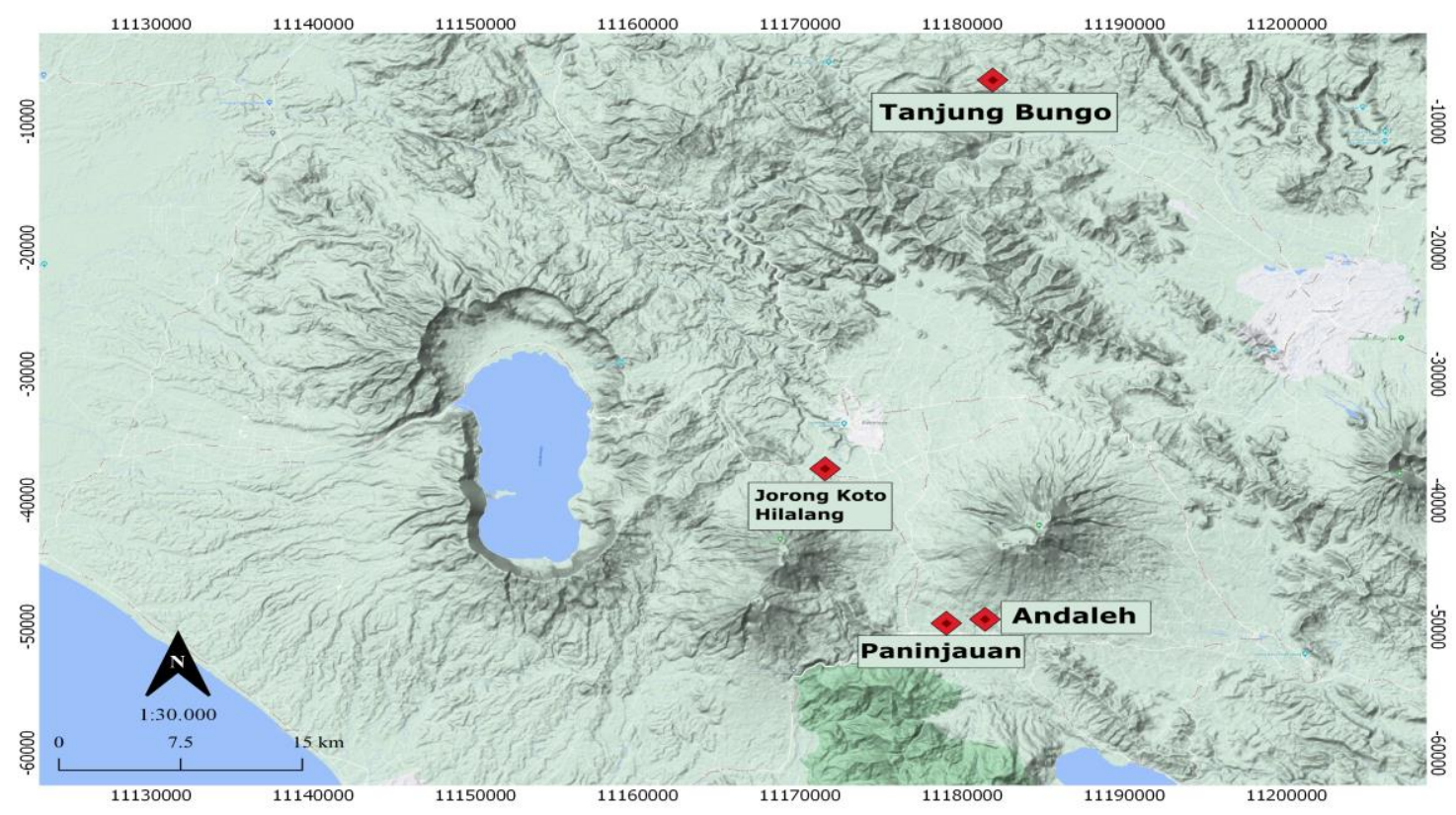

Figure 1. Location of Morus macroura sampling in four regions in West Sumatra.

\subsection{Betulinic Acid Compound Quantification Test}

\subsubsection{Extraction}

300 grams of mashed dry M. macroura leaves were macerated with $\pm 3 \mathrm{~L}$ methanol for 3 days. The actions were repeated 3 times until the extraction is complete. Furthermore, the solvent was evaporated with a rotary evaporator to obtain a thick extract [6].

\subsubsection{Determination of Betulinic Acid Levels by Densitometric Thin Layer Chromatography (TLC) Method}

The extract obtained was used to calculate the betulinic acid contents by testing the densitometric thin layer chromatography method. By preparing a TLC plate with an elution length of $9 \mathrm{~cm}$ for each sample. The TLC-Densitometry analysis begins with sampling at one end of the stationary phase (TLC plate) to form an initial zone. Then the sample was dried. The initial zone at the end of the stationary phase was plunged into the mobile phase Toluene: Ethyl Acetate: Formic Acid (70:25:5, v/v/v). After the mobile phase has moved to the desired distance, then the stationary phase is taken, the mobile phase trapped in the plate is dried, and the zone obtained is detected by adding Lieberman Burchard stain reagent (5 mL Acetic Anhydride + $5 \mathrm{~mL}$ Concentrated Sulfuric Acid $+50 \mathrm{~mL}$ Ethanol PA) [6]. Determination of the content of a compound by measuring the spot density of the separated compound was carried out using the TLCDensitometry method where the sample was then observed under a TLC Scanner. The reading is at a wavelength of $540 \mathrm{~nm}$. The volume of the sample that was spotted was $5 \mu \mathrm{L}$ [7]. 


\section{RESULT AND DISCUSSION}

The determination of betulinic acid levels was calculated by using Thin Layer Chromatography, which is separation by column using 60 F 254 silica gel. Thin Layer Chromatography (TLC) is a qualitative analysis stage indicating a marker compound and figuring out the chemical compound composition in the sample. There are several reasons why this method is used; it is easy to implement, inexpensive, the tools used are simpler, and can be implemented quickly [6]. mobile phase or eluent used is an eluent that can elute so that it is in the elution path, which is Toluene: Ethyl acetate: formic acid (70:25:5). Betulinic acid was not detectable under UV, so a Liebermann-Burchard stain viewer was used.

After the chemical content (betulinic acid) in the extract was determined. The analytical method used was the TLC-densitometry method with the maximum absorption wavelength of betulinic acid which was $540 \mathrm{~nm}$. Determination of betulinic acid levels using the TLC Densitometry method can be done by analyzing betulinic acid to obtain a calibration curve. The following is a table of the concentration of betulinic acid used and the histogram area (Table 1).

Table 1. Concentration and Histogram Area of Betulinic Acid

\begin{tabular}{ll}
\hline $\begin{array}{l}\text { Concentration } \\
(\boldsymbol{\mu g} / \mathbf{m L})\end{array}$ & Histogram Area $(\mathbf{A U})$ \\
\hline 1000 & 4891,0 \\
500 & 2451,6 \\
250 & 903,2 \\
125 & 619,1 \\
62,5 & 287,1 \\
\hline
\end{tabular}

Based on the histogram area values table, the histogram area of the betulinic acid concentrations was $1000 \mathrm{ppm}, 500 \mathrm{ppm}, 250 \mathrm{ppm}, 125 \mathrm{ppm}$, and $62.5 \mathrm{ppm}$. Followed by making a calibration curve with the regression value obtained is 0.9946 . A good regression value is close to 1 because it is less precise in the use of tools. This is what causes the calibration curve lines not to form linear (straight). However, the results obtained are not too far from the existing literature, so they can still be used as a reference. The reconstruction of the concentration value with the histogram area obtained $\mathrm{y}=4.9747 \mathrm{x} 97.287$ with $\mathrm{R} 2$ $=0.9946$. The following is the curve reconstructed from the wide table of the betulinic acid marker histogram.

After obtaining the calibration curve, the concentration in the extract obtained was calculated by entering the extract histogram area (y) in the regression equation for betulinic acid $(y=a+b x)$. Then the concentration of betulinic acid in the extract (x) was obtained. Betulinic acid levels were obtained using the formula:

$\mathrm{BAL}=\frac{(\mathrm{BAC} \times 100 \%)}{\mathrm{ME}}$

Note:

BAL $=$ Betulinic acid levels,

$\mathrm{BAC}=$ betulinic acid concentration in extract,

$\mathrm{ME}=$ Made extract concentration

A comparison of betulinic acid levels was obtained from each location. The following is a comparison table of environmental parameters and levels of betulinic acid (Table 2). Based on our result, the highest betulinic acid level was obtained from $M$. macroura in the Koto Hilalang area, which was $1.0245 \%$, followed by $M$. macroura in the Tanjung Bungo area which was $0.7845 \%$, the Paninjauan area was $0.6667 \%$ and the lowest betulinic acid level was in the Nagari Andaleh area, which was $0.5399 \%$. Related to several environmental parameters that support the growth of $M$. macroura in each location, it has a correlation and influence on the content of betulinic acid levels. The altitude parameter affects the content of betulinic acid compounds. The higher the location, the higher the content of chemical compounds contained,[8] where the higher a place the plant grows, the more it affects the physiology process. Among the four sampling locations, the Koto Hilalang area has the highest altitude, 906 masl. If it is related to the content of its secondary metabolite levels (betulinic acid), the Koto Hilalang area has high levels of betulinic acid content.

Koto Hilalang area has the highest level of betulinic acid caused by soil acidity, and it has a soil $\mathrm{pH}$ of 6.90. This indicates that the soil in Koto Hilalang has a neutral $\mathrm{pH}$. Soil acidity also affects the concentration of chemical compounds in a plant [8]. Internal factors and external factors influence secondary metabolite compounds contained in plants. The genetics of a plant influences internal factors. While the external factors can be influenced by several environmental parameters such as the soil's $\mathrm{pH}$ around the place where it grows and the height of the plant where it grows.

Acidic soil will increase the content of trivalent aluminum $(\mathrm{Al} 3+)$ which can poison plants. These elements' presence affects physiological and biochemical processes in plant tissues [9]. Soil acidity $(\mathrm{pH})$ correlates with altitude (Table 2 ). As the $\mathrm{pH}$ value tends to increase with increasing altitude. One of the contributing factors is 
Table 2. Comparison of altitude and soil chemical property in sampling locations of M. macroura in West Sumatra

\begin{tabular}{|c|c|c|c|c|}
\hline Location & Altitude (masl) & Soil pH & Criteria & $\begin{array}{c}\text { Betulinic acid } \\
\text { level }(\%)\end{array}$ \\
\hline $\begin{array}{l}\text { Jorong Koto Hilalang, } \\
\text { Kabupaten Agam }\end{array}$ & $906 \mathrm{~m}$ & 6,90 & Neutral & $1,0245 \%$ \\
\hline $\begin{array}{l}\text { Nagari Tanjuang Bungo, Kabupaten } \\
\text { Lima Puluh Kota }\end{array}$ & $849 \mathrm{~m}$ & 5,97 & Acidic & $0,7845 \%$ \\
\hline $\begin{array}{l}\text { Nagari Paninjauan, } \\
\text { Kabupaten Tanah Datar }\end{array}$ & $807 \mathrm{~m}$ & 5,34 & Acidic & $0,6667 \%$ \\
\hline $\begin{array}{l}\text { Nagari Andaleh, } \\
\text { Kabupaten Tanah Datar }\end{array}$ & $758 \mathrm{~m}$ & 5,25 & Acidic & $0,5399 \%$ \\
\hline
\end{tabular}

higher soil organic matter content. The increase in $\mathrm{pH}$ is due to the decomposition process of various organic matter types resulting in alkaline cations. The release of basic cations into the soil solution causes the soil to become saturated with these cations and ultimately increases the $\mathrm{pH}$.

The content percentage of betulinic acid compounds as secondary metabolites has a difference in each location. This is because each individual Andalas tree that grows in each location has a level of secondary metabolite biosynthesis that is produced. Suppose it is related to the molecular variation of Andalas (Morus macroura) plants. In that case, it has a relationship where plant genetic differences also affect the production of secondary metabolites of a plant.[10] Plants that grow in different ecotypes contain different levels of secondary metabolites. In this study, Morus macroura's samples had variations in its genome from four research locations and had variations in its betulinic acid content. The differences in the secondary metabolite content of a plant were influenced by environmental factors and plant genetics as internal factors that affect secondary metabolites production [10].

\section{CONCLUSION}

According to this study, variations of betulinic acid content in Morus macroura from four regions were varied. The most contribute variables were elevation and soil's pH. Suggestion for further studies in this research is to calculate the levels of betulinic acid in Morus macroura in West Sumatra in relation to the soil nutrient content and testing of betulinic acid in Morus macroura from each location against the HIV-infected cells.

\section{REFERENCES}

[1] D. Arbain, Bioactive Compounds from Sumatran Medicinal Plants, Nat Prod Comm 7 (2012) 685-814.

[2] E. Nuratika, N. Aseny, Syamsuardi, Nurainas, Fitmawati Friardi, Clarification of Sumatran Mulberry (Morus macroura var. macroura, Moraceae) from West Sumatra, Indonesia using Nucleus Ribosomal ITS (Internal Transcribed Spacer) Gene, Indian Journal of Agricultural Research A-508 (2020) 1-6

[3] The Indonesia Wildlife Conservation, Daftar Flora Maskot Provinsi, 2017. Accessed on March, 2019. http://www.iwf.or.id/detail_flora/67. [In Bahasa Indonesia]

[4] E.H. Hakim, S.A. Achmad, L. Makmur, Y. Manjang, L.D. Juliawati, S. Kusuma, U. Supratman, R. Tamin, Sejumlah Senyawa Fenolik dari Tumbuhan Morus Macroura Miq. (Moraceae), In Proceedings Seminar Kimia Bersama ITB-UKM Kedua, Bandung, 2, 1995 , pp. 21-29. [In Bahasa Indonesia]

[5] E.H. Hakim, S.A. Achmad, L.D. Juliawaty, L. Makmur, Y.M. Syah, N. Aimi, M. Kitajima, H. Takayama, E.L. Ghisalberti, Prenylated Flavonoids and Related Compounds of the Indonesian Artocarpus (Moraceae), Journal of Natural Medicine 60 (2006) 161-184.

[6] T. Galgon, D.Höke, B. Dräger, Identification and Quantification of Betulinic Acid, Journal phytochemical analysis 10(4) (1999) 187-190. 
[7] N. Sugihartini, A. Fudholi, S. Pramono, S. Sismindari, Validation method of quantitative analysis of epigallocathecin gallat by thin layer chromatography densitometry, Pharmaciana 2(1) (2012) 81-87

[8] E. Nurnasari, Djumali, Pengaruh Kondisi Ketinggian Tempat Terhadap Produksi dan Mutu Tembakau Temanggung. Buletin Tanaman Tembakau, Serat \& Minyak Industri 2(2), 2010, ISSN 2085-6717. [In Bahasa Indonesia]
[9] R.A. Cyamweshi, N.L Nabahungu, A. Mukashema, V. Ruganzu, M.C. Gatarayiha, A Nduwumuremyi, J.J. Mbonigaba, Enhancing nutrient availability and coffee yield on acid soils of the central plateau of Southern Rwanda, Global Journal of Agricultural Research 2(2) (2014) 44-55.

[10] F. Wika, Uji Anatomi, Metabolit Sekunder, dan Molekuler Sansevieria trifasciata, Master Thesis, Program Pascasarjana Univeristas Sebelas Maret, Surakarta, 2009. [In Bahasa Indonesia] 